\title{
INNOVATIVE URBAN FARMING TECHNIQUES FOR SUSTAINABILITY OF CITIES: FROM FARM TO FORK - CASE OF THE CITY LANUVIO, ROME, ITALY
}

\author{
Sangodoyin Olakunle. $\mathrm{M}^{1}$, Shehata Mariam ${ }^{2}$, D’Aprile Andrea ${ }^{3}$, Calore Giuseppe ${ }^{4}$, Lorianne Ginot ${ }^{5}$, Correrella \\ Maia ${ }^{6}$, Elian Mariam ${ }^{7}$, Aly Nada ${ }^{8}$, Aboughanema Salma ${ }^{9}$, Ali Sohaila ${ }^{10}$, Aboulnaga Mohsen ${ }^{11}$ \\ ${ }^{1 *}$ Department of Food Engineering, Faculty of Engineering, \\ Ladoke Akintola University of Technology, Ogbomoso, Oyo State, Nigeria \\ $2^{*}, 7,8,9,10$ Department of Architectural and Technology Engineering Programme, Faculty of Engineering, \\ Cairo University, Egypt \\ 3, 4, 5, 6 Alma Mater Studiorum University of Bologna, Italy \\ ${ }^{11}$ Professor of Sustainable Built Environments, Department of Architecture, Faculty of Engineering, \\ Cairo University, Egypt
}

\begin{abstract}
Urban areas and cities globally encounter many challenges to confront vast urbanization and climate change impacts. Urban farming is one of major responses to some of these defies. Such challenges are manifested in Lanuvio, a municipality near Rome situated in 'Castelli Romani Regional Park', use to have high cultural, historical, archeological and naturalistic values, but the site of ARES (once served as a fire station) is now vacant land, hence considered a waste of resources that decreases its value economically, socially and environmentally. Urban farming can assist in transforming cities to be generative, resilient and sustainable. This paper presents a project (Green Symphony) transformation that provides the citizens of Lanuvio with smart and sustainable technologies focusing on urban agriculture. The objective of the study is to transform the abundant site to be a generative urban farm while making people aware of the importance of healthy food and creating connectivity between citizens and tourists. Indeed, aquaponic systems, permaculture, green walls, vertical farming, combined with energy harvesting from footsteps, solar panels, water close circuit, and rainwater collection are incorporated. Organic waste is also transformed into fertilizer, which contributes to the creation of a self-sustained farm. The site has been developed as a social hub and a business model, including: strategy, marketing and operations plans are developed to estimate the operation costs and labour management. Results show that the developed site can generate 7 tons yearly of vegetables, fruits, herbs and fish, besides creating 3 stable jobs. The investment costs are paid off after a maximum of 5 years and the financial balance is annually positive and 1.7 tons of produce. Finally, the vacant land is transformed into a social hub
\end{abstract}

and multi-functional green gardens to increase livability and targeted SDG 3, 7, 9, 11, 12, 13 and 15.

Keywords - Sustainable cities, social sustainability, SDGs, urban farming, Lanuvio city, Italy.

\section{INTRODUCTION}

Cities generate over $80 \%$ of the global GDP and attract more people due to their economic growth [1]. Rapid growth in population leads to a huge increase in energy demands, $\mathrm{CO}_{2}$ emissions, and food requirements in cities [2-3]. Climate change (CC) is considered as one of the biggest challenges nowadays. It affects the environment and cities negatively in various forms (severe events, storms, floods and health) [4-6]. The global temperature has increased by $1.4^{\circ} \mathrm{F}$ in the last 140 years and the $\mathrm{CO}_{2}$ level in the atmosphere has become 400.71 parts per billion.

Also, the cover of the world's forest has decreased by 1.5 million $\mathrm{km}^{2}$ in 12 years [7]. In Italy, CC increased air pollution, floods, droughts, coastal erosion and caused reduction in agriculture. This affects food and water security in most regions [8].

Urban farms play an escalating and crucial role in food security and in generating clean and local food $[9,10]$. Urban farms also create new job opportunities, boost the economic growth, and contribute to the GDP, while eventually becoming green spots of the cities and acting as social catalysts [11-12]. Urban farming is a key component in improving local economy, increasing social integration, and achieving environmental sustainability [13]. Urban farming has been increasing in cities. For instance, more than 21,000 ha in Cagayan de Oro City, Philippines, $12 \%$ of urban land in Havana, Cuba and more than 11,000 ha in Jakarta, Indonesia 


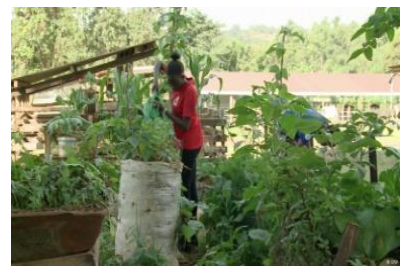

Fig. 1 (a) Urban farming in Uganda's schools

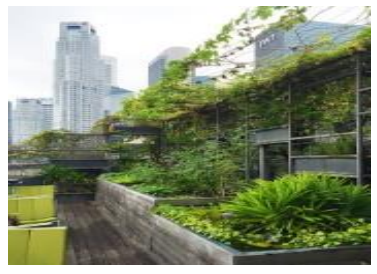

Fig. 1 (b) Urban farms, Singapore is dedicated for agriculture production [14-16]. Figure 1 presents some examples of urban farming in different cities.

According to the Food and Agriculture Organization of the United Nations (FAO), one quarter of the world's population is provided by food through urban and peri-urban farms and this number is expected to rise as shown in Box 1 [17]. With urban farms starting to be integrated to the city fabrics such as rooftop urban farms, their economic, social, and environmental values increase as well. Urban farming provides the community with organic and clean food mainly vegetables, herbs, and fruits [18]. Hence, it ensures food selfsufficiency and security, as well as it creates solutions to organic waste and improves the air quality mitigating $\mathrm{CO}_{2}$ emissions.

New technologies in agriculture have been developed to deal with areas with low soil fertility and water availability, cultivation in limited spaces, and minimize the production impact to the environment and human health [13]. Some of these technologies are aquaponic and hydroponic systems, green walls, vertical farming (Figure 2) as well as permaculture, energy from renewable sources, transforming organic wastes into fertilizers and rainwater harvesting [1922].

Lanuvio is not far from the challenges of climate change (CC) and the need for food security. It is a village situated in "Castelli Romani Regional Park" close to Rome, in the region of Lazio, Italy. The area has high cultural, historical, archeological and naturalistic values that should be maximized and promoted. It is a popular and touristic place with festivals and social events promoting local-food and traditionalism [23]. The site of ARES $118\left(2,500 \mathrm{~m}^{2}\right)$ was once used as a fire station. However, it is now a vacant land with no social or economic value. It is located next to the city center, 800 meters away from the main square and is reachable by train from other parts of Italy.

Box 1: Scale of urban farming in providing clean food

'One quarter of the world's population is provided by food through urban and peri-urban farms and this number is expected to rise.'

Food and Agriculture Organization (FAO) - United Nations

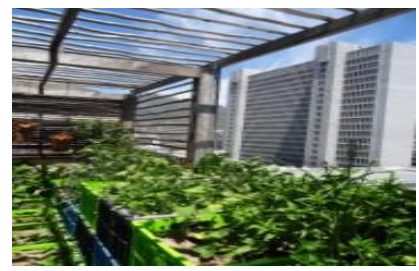

Fig. 1 (c) Urban farm South Africa

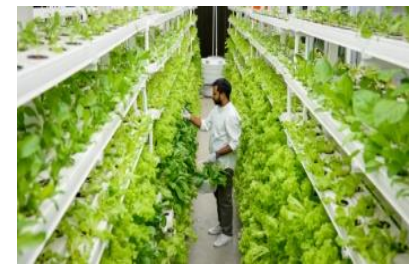

in Fig. 1 (d) Urban farming in India
Fig.1 Examples of urban farming in different cities [24-27]

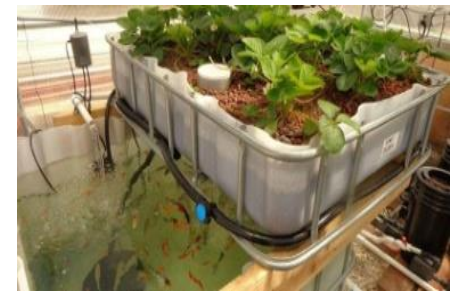

Fig. 2 (a) Aquaponic systems

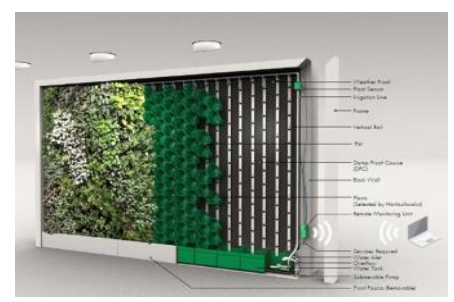

Fig. 2 (c) Green walls

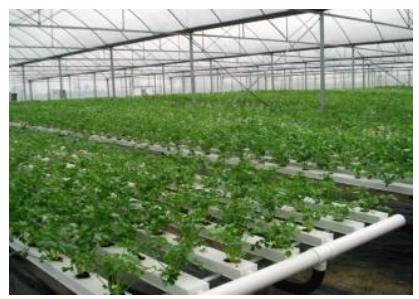

Fig. 2 (b) Hydroponic system

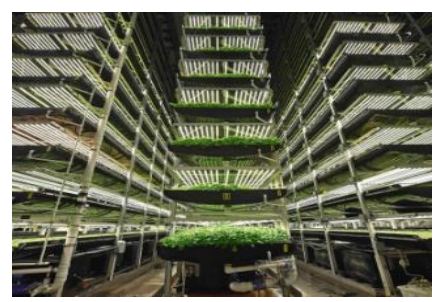

Fig. 2 (d) Vertical farms
Fig. 2 Examples of urban farming types and technologies in cities [28-31]

This paper presents a study conducted on an abundant site in Lanuvio - Rome, Italy utilising urban farm innovative technologies and integrating smart solutions to make this site a green hub in the city, generative and sustainable (economically viable, socially viable and environmentally viable). It also presents a conceptual project - named Green Symphony - that provides a social hub for the citizens of Lanuvio with smart and sustainable technologies focusing on agriculture.

\section{OBJECTIVES}

Focusing on the needs of the citizens and the necessity to restore the site (There is a train station 28 minutes away on foot next to the site as shown in Figure 3), the objectives of Green Symphony project were to transform the 


\section{International Journal of Engineering Applied Sciences and Technology, 2021 \\ Vol. 6, Issue 1, ISSN No. 2455-2143, Pages 29-42 \\ Published Online May 2021 in IJEAST (http://www.ijeast.com)}

abundant site of ARES 118 to be a sustainable node, an educational hub, and a social innovation area to increase the livability of the city. The conceptual project links arts, like music, and agriculture creating a community-focused farm. It reaches out to the community while using innovative environmentally-friendly approaches, smart technologies to preserve energy, water and to produce pesticide-free food while focusing on the UN 2030 Agenda and SDGs, mainly SDG 3, 7, 9, 11, 12, 13 and 15 as illustrated in Figure 4.

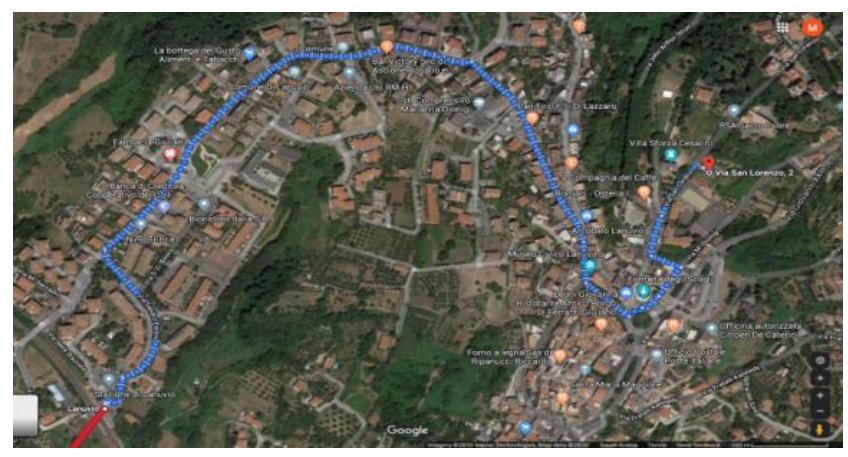

Fig. 3 (a) Route to the site

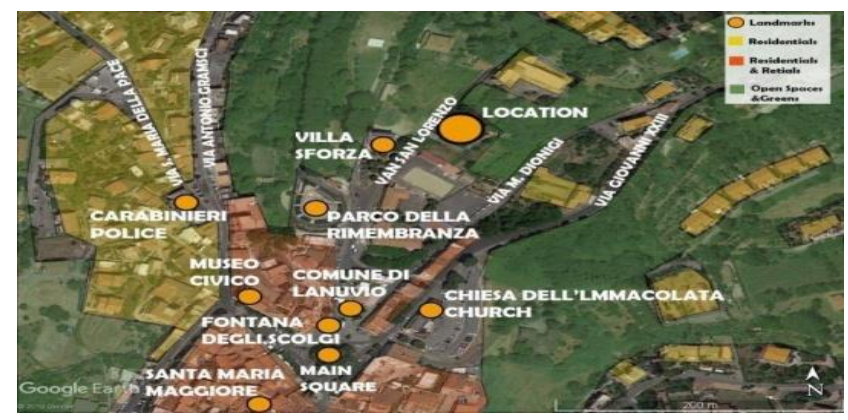

Fig. 3 (b) Site's surroundings

Fig. 3 Accessibility to the site on foot and the surroundings Image source: Authors based on Google Maps, 2020
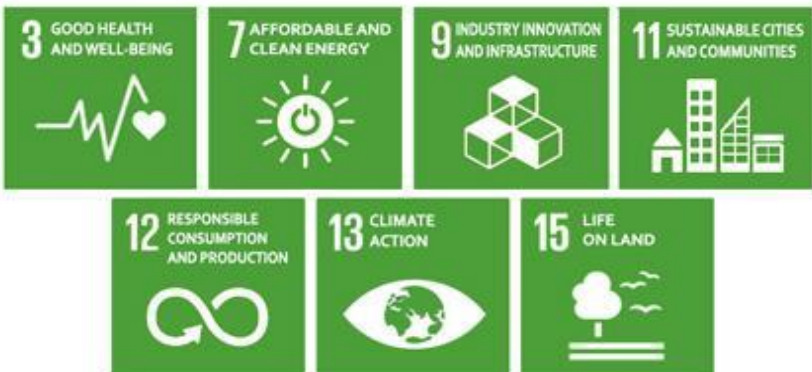

Fig. 4 Sustainable development goals for 2030 and the project targets
Image Source: UN Global compact, 2018

\section{ISSUES AND CHALLENGE}

With the increase in population and damages due to climate change, cities are lacking the resources to support their citizens. Therefore, cities are usually thought of as congested places lacking natural life and green sites. To change this situation, action is required, that ensures the sustainability of the city and meets the needs of the community. The site of the study is located in the city of Lanuvio, Italy at coordinate: $42^{\circ} 14^{\prime} 20.29^{\prime \prime} \mathrm{N} 13^{\circ} 42^{\prime} 56.04 " \mathrm{E}$ as illustrated in Figure 5. There are several challenges concerning the site of the study, there are as follows:

- The site being small $\left(2,500 \mathrm{~m}^{2}\right.$ only) with one usable building;

- The land being abandoned and the building in a poor state (Figure 5);

- Located along only one road and the only entrance;

- Being a dull spot among the historic sites around it;

- The main building being wall bearing with minimal possible changes

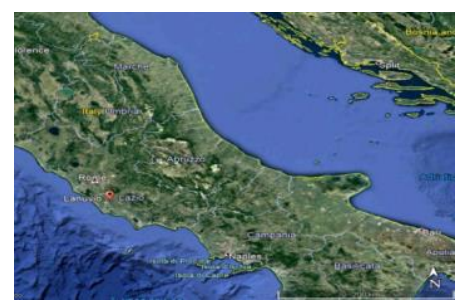

Fig. 5 (a) Satellite footage of Lanuvio's location

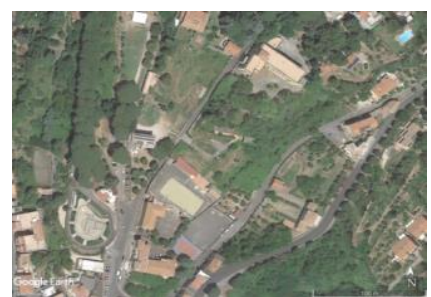

Fig. 5 (b) Satellite footage of the site
Fig. 5 Satellite footage of Lanuvio and the site location in Ron metropolitan, Italy

Images source: Google Earth, 2020

\section{Methodology}

This project study is a product of the participation of the team "FENICE" in the international competition of UrbanFarm2020. The methodology depends on two approaches: a) a theoretical and analytical approach; and b) an applied approach. The analytical approach depends on the evaluation of the given site and its surroundings, and it produces a number of solutions to achieve its goals and objectives. These solutions include architectural, agricultural, social and ecological ones [32]. The applied approach is centered on integrating the environmental and energy systems as well as smart technologies including the urban farming systems. Figures 6 and Figure 7 show the exterior state of the deserted building and the site shed. 


\section{International Journal of Engineering Applied Sciences and Technology, 2021 \\ Vol. 6, Issue 1, ISSN No. 2455-2143, Pages 29-42 \\ Published Online May 2021 in IJEAST (http://www.ijeast.com)}

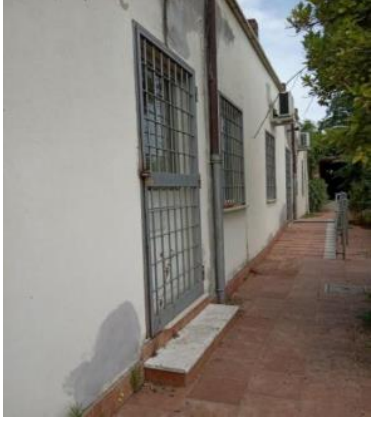

Fig. 6 Building's exterior situation

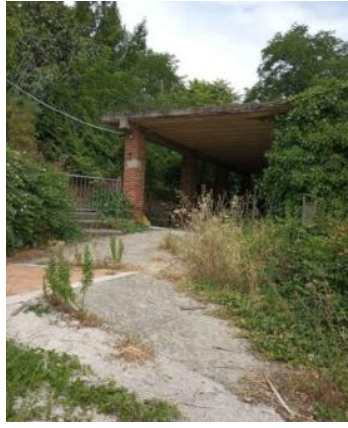

Fig. 7 Site and Shed's situation

\section{IMAGES' SOURCE: URBAN FARM 2020 [32]}

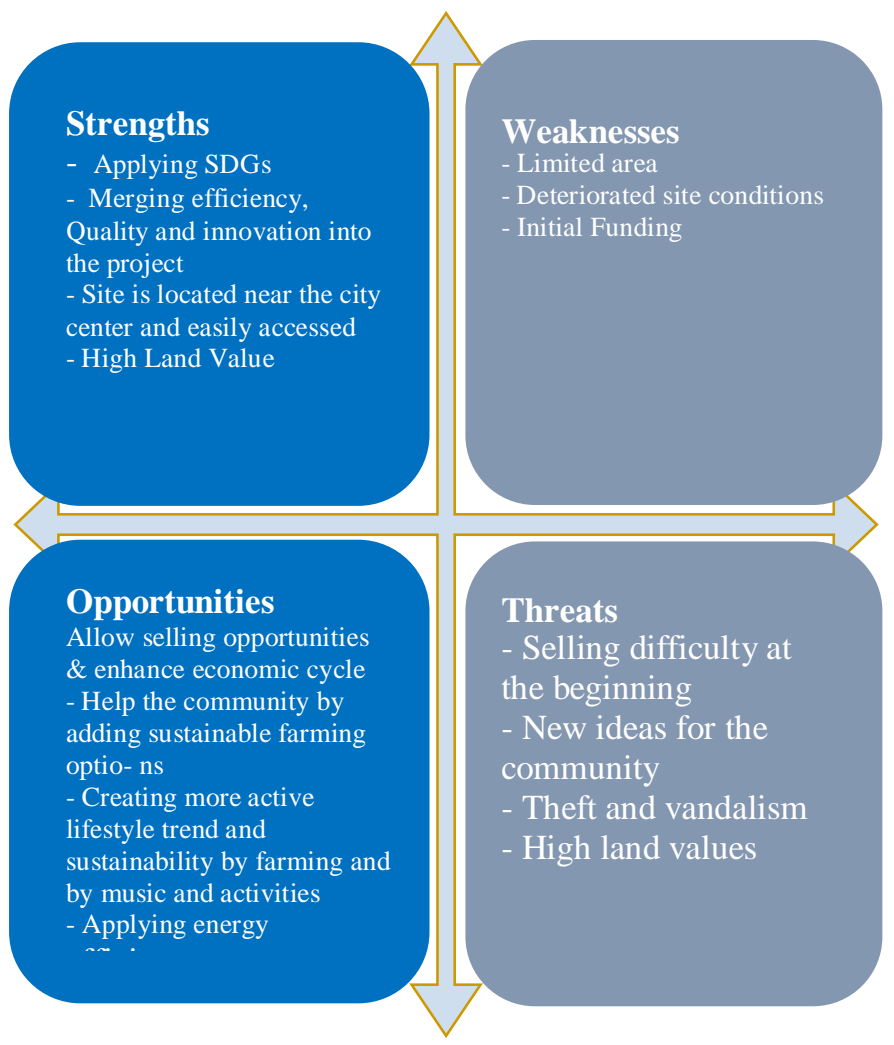

Fig. 8 SWOT analysis of the study project Source: Authors

\section{SWOT ANALYSIS}

It is imperative to conduct a SWOT analysis of the study project to assess the strengths, weaknesses, opportunities and threats. Figure 8 summarizes the SWOT analysis that was carried out for per-assessment. It is clear from the figure that project strengths and opportunities are of added value, but nevertheless the threats and weakness were addressed in the project assessment in the following parts.

\section{THE STUDY}

The study's concept of architectural innovative and smart solution includes 6 fields: a) environmental systems; b) energy; c) water; d) materials; e) emissions; and f) urban farming are presented in Figure 9 and discussed in the following section.

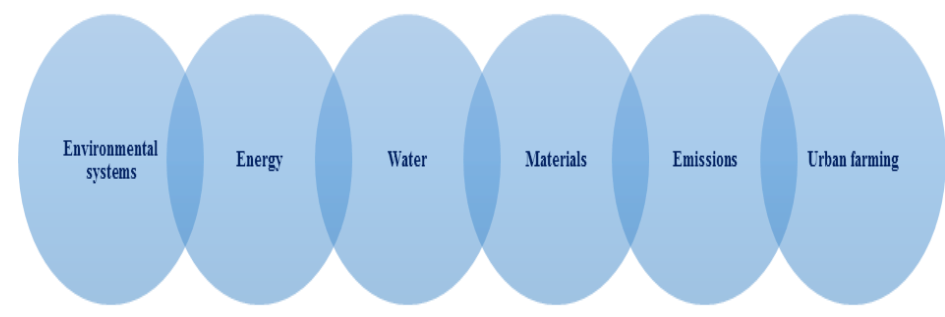

Fig. 9 The 6 sections examined in the study

\subsection{CONCEPT}

The name FENICE was inspired by the phoenix where in ancient Greek folklore, a phoenix is a long-lived bird that cyclically regenerated or is otherwise born again [33]. The study approach and slogan is basically to rebuild from ashes. We therefore, rebuild the current land from its own ashes into an urban farm, which has a community focused approach. In order to create a farm that is fulfilling to the citizens' needs and making use of the abandoned site of Lanuvio, the project study focuses on linking arts (music) and agriculture through creating a community-focused farm. Thus, the urban farm is called 'Green Symphony' to emphasize this link and create social synergy. The project has an area to host events and allow for social interaction. It also reaches out to the community while exploiting innovative environmentallyfriendly approaches, smart technologies to conserve energy, water use, yet produce pesticide-free food as well as focusing on 2030's sustainable development goals (SDGs).

\subsection{ARCHITECTURAL SOLUTIONS}

The project consists of 4 main spaces: workshops, a permaculture garden, outdoor recreational spaces, and a kitchen. The two buildings are developed to be well-insulated to save energy (heating/ cooling). The remaining space will host a number of recreational activities with primary views of the historic sites and area dedicated to hosting events in the farm as shown in Figure 10; and details are in Table 1.

\subsection{ENVIRONMENTAL SOLUTIONS}

The restoration and valorization of degraded sites is part of the Regulation L. 29/97 that protects the regional park; thus, it is one of the main goals of the region of Lazio. Within this scope, Green Symphony could be a solution, as it provides local food and hosts events with economy of energy, water, 


\section{International Journal of Engineering Applied Sciences and Technology, 2021 \\ Vol. 6, Issue 1, ISSN No. 2455-2143, Pages 29-42 \\ Published Online May 2021 in IJEAST (http://www.ijeast.com)}

the use of low impact materials, and a negative carbon footprint (avoidance of impact).

Table 1: Illustration for the Architectural areas, locations and functions

\section{Area Location \\ Function}

$\begin{array}{ccc}\text { Worksho } & \begin{array}{c}\text { Under the old } \\ \text { p area }\end{array} & \begin{array}{c}\text { Seminar area enclosed by glass } \\ \text { shed that was } \\ \text { used formerly } \\ \text { for }\end{array} \\ & \begin{array}{c}\text { walls, equipped with a wide screen } \\ \text { ambulances. }\end{array}\end{array}$

\begin{tabular}{|c|c|c|}
\hline Office & Main Building & $\begin{array}{l}\text { Developed for the management of } \\
\text { the farm's activities. }\end{array}$ \\
\hline $\begin{array}{l}\text { Green } \\
\text { house }\end{array}$ & $\begin{array}{l}\text { On the roof of } \\
\text { the main } \\
\text { building }\end{array}$ & $\begin{array}{l}\text { Aquaponics system of agriculture } \\
\text { is used where columns and trays } \\
\text { are rented to the community. }\end{array}$ \\
\hline Kitchen & $\begin{array}{l}\text { The heart of } \\
\text { the main } \\
\text { building. }\end{array}$ & $\begin{array}{l}\text { Sharing, collaborating, co- } \\
\text { creating, and raising awareness are } \\
\text { the main purposes for teaching the } \\
\text { community the basics of using } \\
\text { fresh produce to prepare } \\
\text { traditional Italian dishes. }\end{array}$ \\
\hline $\begin{array}{l}\text { Eating } \\
\text { area }\end{array}$ & $\begin{array}{l}\text { Attached to the } \\
\text { kitchen in the } \\
\text { main building. }\end{array}$ & $\begin{array}{l}\text { The community can order food } \\
\text { according to the produce of the } \\
\text { farm and the kitchen. }\end{array}$ \\
\hline $\begin{array}{l}\text { Storage } \\
\text { room }\end{array}$ & $\begin{array}{l}\text { Next to the } \\
\text { kitchen in the } \\
\text { main building. }\end{array}$ & $\begin{array}{l}\text { The produce could be stored for a } \\
\text { short time to be packaged and sent } \\
\text { out to be sold. }\end{array}$ \\
\hline
\end{tabular}

\section{Outdoor spaces}

An events area and interactive space in the landscape is designed to host different activities to boost the social dimension, in addition to a bike park.

$\begin{gathered}\text { External } \\ \text { booths }\end{gathered} \begin{gathered}\text { Attached to the } \\ \text { outer fence } \\ \text { facing the } \\ \text { main street. }\end{gathered}$
For selling the excess products of
fruit and vegetables.

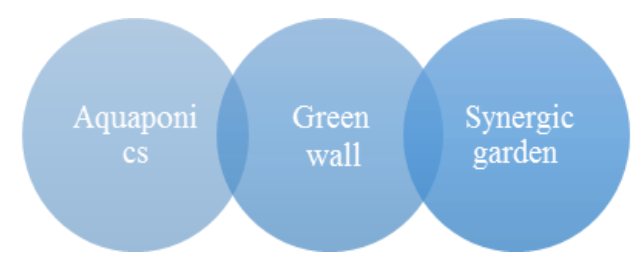

Fig.10 Elements of the study project planning in Lanuvio city, Italy (source: authors)

\subsubsection{Energy}

Energy production is one of the most critical factors that affect the environment. The building's envelop is insulated and the heat from the kitchen is harvested to decrease cooling loads. The pond is covered by a removable radiant barrier $\left(\mathrm{TekFoil}^{\circledR}\right)$ to preserve moderate temperatures during the winter. Dimmable LED lighting units combined with $\mathrm{ABB}$ i-bus ${ }^{\circledR}$ light and occupancy sensors are also used indoors to adjust light intensity and automatic turn off of the lights. Lumimotion ${ }^{\circledR}$ technology, in the landscape, is applied for turning the light on automatically when someone moves within a 10 meters radius. These technologies reduce the energy use of lighting up to $60 \%$. Moreover, renewable energy sources are chosen according to local abundance and 25 solar photovoltaic cells (315 $\mathrm{kWp}$ ) are installed on top roofs. Each PV cell produces 320 $\mathrm{kWh}$ annually so the total solar energy produced will be 8 MW/year and it can be used to operate the two buildings and the pumps [34]. However, solar energy may not be sufficient to cover all the energy needs, hence, the farm is also supplied in certified $100 \%$ green electricity. Finally, piezoelectric Pavegen ${ }^{\circledR}$ tiles generate an average of 5 watts at $12-48$ volts DC per footstep. This energy is used to load the batteries of humidity sensors in the garden.

\subsubsection{Water}

The aquaponic and green wall systems both use water from the fish pond to feed plants. This closed circuit reduces water consumption by $90 \%$ and prevents water waste. Likewise, saving water is a key aspect of the permaculture concept, so that mulching and a drip irrigation system in the garden are essential. Since Lanuvio has had substantial rates of rainy days $\left(827 \mathrm{~mm} / \mathrm{m}^{2}\right.$ between 2003 and 2018, according to the Regional Agency for Environmental Issues (ARPA)); the rainwater is collected through buildings, gutters and channels in the garden, and stored in an underground tank size of $5 \mathrm{~m}^{3}$ [35]. Such water can be used for farm irrigation instead of drinkable water. During drought periods, the needs in water are supplemented by the water network. In addition, the Internet of Things (IoT) technology can nowadays be applied in agriculture and save water up to $70 \%$ [36].

\subsubsection{Materials}

Green Symphony farm enrolls in the "Civiltà Contadina", which is non-profit association that is fostering biodiversity 


\section{International Journal of Engineering Applied Sciences and Technology, 2021 \\ Vol. 6, Issue 1, ISSN No. 2455-2143, Pages 29-42 \\ Published Online May 2021 in IJEAST (http://www.ijeast.com)}

conservation by exchanging native seeds. Hence, it provides the first seeds that are restituted after one year, and then the remaining seeds are used for self-reproduction [37]. Materials used for renovations come from secondary raw materials; particularly, the columns of the aquaponics system and the irrigation system in the garden are built with recycled tubes. In the kitchen, no disposable tableware is used and food is stored into glass containers or jars. Wastes generated by the activities of the site are collected, carefully separated, and sent to the municipal waste treatment.

\subsubsection{Emissions}

The carbon footprint (CF) of the life cycle of materials used in the study project has been computed based on data from the ADEME database - a French Agency for Environment) since no equivalent were found for Italian figures and similarity [38]. Table 1 (Appendix - A) lists the results of the project when is already implemented. The total $\mathrm{CF}$ generated is $-77 \mathrm{tCO}_{2} / \mathrm{yr}$ mainly due to the good yields of both permaculture and aquaponics without any pesticides or fertilizers industrially produced. The $\mathrm{CF}$ of energy consumption is estimated at a maximum $8 \mathrm{tCO}_{2} /$ year. This is due to heating, kitchen activities and pumps functioning, thus, the overall farm $\mathrm{CF}$ is $-69 \mathrm{tCO}_{2} / \mathrm{yr}$. However, the renovation of the site has a $\mathrm{CF}$ estimated at $100 \mathrm{tCO}_{2}$ according to a computation suggested by the ADEME for housing renovation (2 $\mathrm{tCO}_{2} / \mathrm{yr}$ ). All in all, Green Symphony allows it to produce food and to enjoy recreational and didactical activities with a life cycle negative carbon footprint $\left(-67 \mathrm{tCO}_{2} / \mathrm{yr}\right)$.

\section{URBAN FARM DESIGN}

\subsection{Surroundings and Indoor area}

Green Symphony farm consists of a kitchen with an aquaponic farm on the rooftop, a workshop room, a synergic garden, a green wall and outdoor recreational spaces including a pond. The kitchen is situated in the main building offering cooking training using vegetables harvested from the farm and fish from aquaponics (refer to Table 2 in appendix $\mathrm{A}$ for the number of sessions per year). Different innovative systems for agriculture are applied in the project (Figure 11).

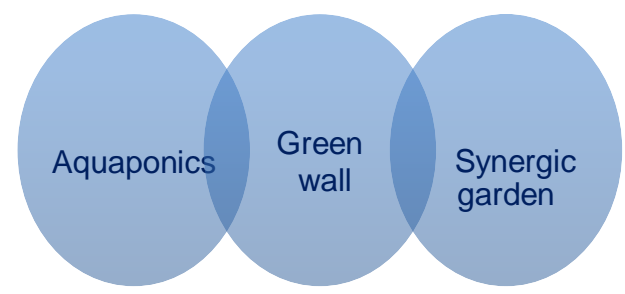

Fig. 11 Elements of the plan of the study project

\subsection{The Aquaponic system}

The aquaponic system is a new agricultural technique used to grow plants, and it combines the hydroponic system (soilless agriculture on columns) with the aquaculture (fish breeding). An aquaponic closed-cycle system, that starts from an external pool containing fish and nutrients, and arrives inside the rooftop greenhouse, where hydroponic columns are present with plants, is developed in this project. A vertical farm system that allows for good production in the project's space (about $65 \mathrm{~m}^{2}$ ) is created.

The pool

In order to guarantee a good amount of nutrients to vegetables production, a $50 \mathrm{~m}^{3}$ pool is required; thus, it was decided to breed carps with a density of around $15 \mathrm{~kg} / \mathrm{m}^{3}$.

\section{The fishes}

The study highlights that Cyprinus Carpio (common carp) originally from East Europe, resists a high range of water temperatures between $4^{\circ} \mathrm{C}$ and $34^{\circ} \mathrm{C}$. Together the common carp with mirror carp (same species) and the Amur carp (Ctenopharyngodon idella) are generated. All these fish are edible, and their breeding is widespread in aquaculture.

\section{The columns and big pots}

The vertical hydroponic columns are pipes filled with an inert substrate like expanded clay. The typical plants that can be cultivated are presented in Figure 12. Near the columns, some big pots are integrated and filled with the same inert substrate of the columns that are used to grow bigger vegetables like tomatoes or cucumbers. Humidity sensors are present in the greenhouse to regulate the water flow.

\section{Estimated production}

An aquaponic system guarantees a faster plant growing and longer fructification time, with a reduction of water wasting of $90 \%$. Based on a study conducted by a leading Italian company, it was found that there are some estimates which calculated a production between 6 and $11 \mathrm{~kg} /$ years of vegetables every $453 \mathrm{~kg}$ of fishes [39]. The estimated production can be found in Figure 12. By considering the data and equally dividing the surface in 4 sections, it can obtain $16.25 \mathrm{~m}^{2}$ for each type of vegetables. Table 2 lists the system's anticipated vegetables production around 5.3 tons/year.

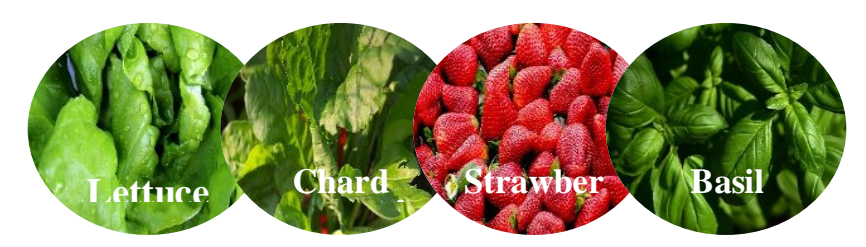

Fig. 12 Types and Production of the Vegetables and Fruits used in the aquaponic system [39] 


\section{International Journal of Engineering Applied Sciences and Technology, 2021 \\ Vol. 6, Issue 1, ISSN No. 2455-2143, Pages 29-42 \\ Published Online May 2021 in IJEAST (http://www.ijeast.com)}

Table 2 Summary of the yield per year of the aquaponic system

\begin{tabular}{lllll} 
Vegetables & $\begin{array}{l}\text { Production } \\
\text { Kg/m²/year }\end{array}$ & Surface & Kg/year & Tons/year \\
\hline Lettuce & 95 & 16.25 & 1543.75 & 1,54375 \\
Chard & 75 & 16.25 & 1218.75 & 1,21875 \\
Strawberries & 58.80 & 16.25 & 955.50 & 0,9555 \\
Basil & 97.76 & 16.25 & 1588.60 & 1,5886 \\
& & & &
\end{tabular}
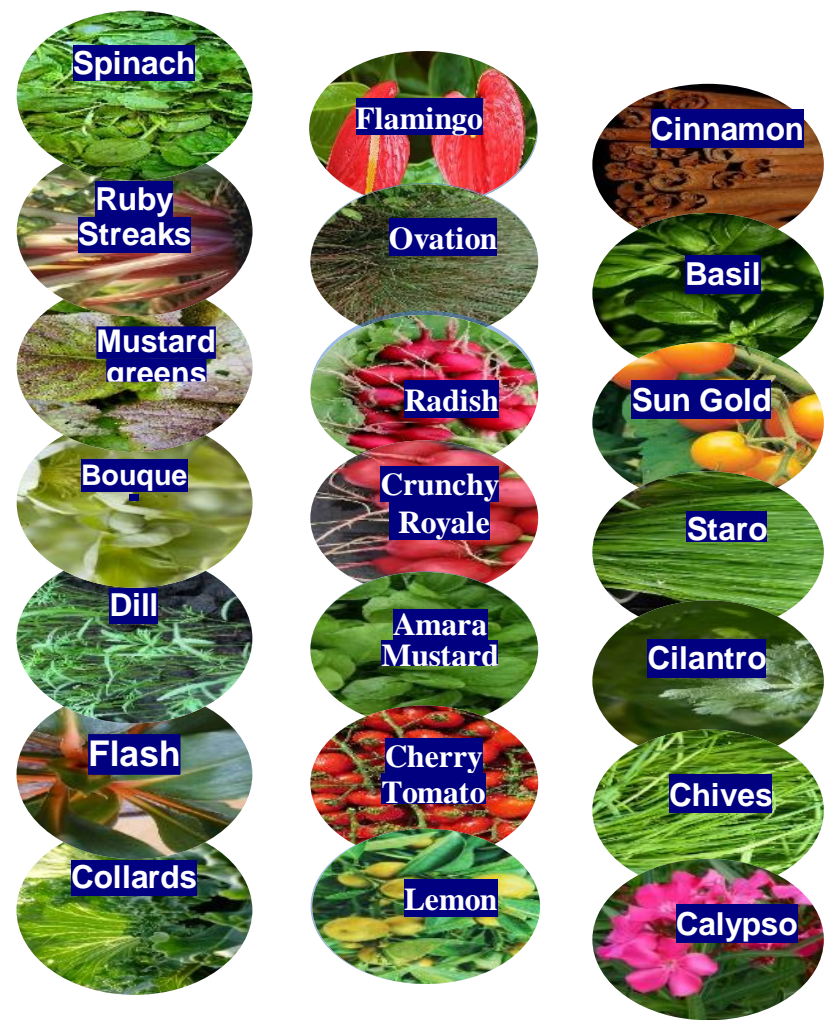

Fig. 13 Types of vegetables, herbs and fruits cultivated in the Green Wall system [40-49].

\subsection{Green Wall}

At the city scale, green walls contribute to the recovery of degraded areas without occupying extra space. Thus, a green wall is developed in the project, not only for beauty, but also as an urban gardening, which increases yield of food production.
Green wall system

The green wall will be fixed to the front side of the main building. The wall consists of 64 modular trays; pots will be placed on each modular tray in this system and secured by bars. In this case, an automatic irrigation system ensures good plant growth.

\section{Green wall plants}

Vegetable seeds and stems grow in a green wall making use of sterile potting mix. Most plants will be harvested continuously. The plants include 22 types (Figure 13).

\section{Pests and Pathogens}

The biological control and mechanical removal of pests, e.g., destroying cabbage moth eggs and larvae and leaf miners by hand, yet will control pests and pathogens.

\section{Irrigation}

Water is transported to the plants by small pipes made of second-hand plastics. Every tier of planter receives irrigation from four drip emitters (2/ cell). A gutter system runs along each tier of planter, collecting excess water and draining it to the fish pond.

\subsection{Synergic Garden}

Synergic gardening is the Mediterranean climate version of natural farming and it is the application of permaculture philosophy. Vegetables will be associated with each other and with aromatic herbs in order to enable exchange of nutrients.

\section{Garden structure}

The surface dedicated to synergic agriculture $\left(745 \mathrm{~m}^{2}\right)$ will be splitted in two parts: one composed of 12 raised circular shrubberies with aromatic herbs combined with vegetables and one with 24 mounds of soil where crop rotation of vegetables is applied. The shrubberies will be $1 \mathrm{~m}$ high and $4 \mathrm{~m}$ diameter. Mounds will be $0.7 \mathrm{~m}$ high, 2 meters wide and 8 meters long. The total cultivated area will be $540 \mathrm{~m}^{2}$, hence $205 \mathrm{~m}^{2}$ are left for paths (large enough to host scholar groups).

\section{Crops combinations}

Regarding the aromatic herbs combined with vegetable shrubberies, the combinations are listed below and Table 3, in the Appendix A, shows the benefits from those aromatic plants.

- Rosemary with carrots, salvia and beans;

- Salvia with carrots, beans, rosemary, fennel;

- Mint with tomato, broccoli, lettuce, carrots, and potatoes;

- Basil with fennel, lettuce, cucumber, tomatoes;

- Chamomile with onion; and

- Thyme with spinach and pumpkins.

\section{Estimated production}




\section{International Journal of Engineering Applied Sciences and Technology, 2021 \\ Vol. 6, Issue 1, ISSN No. 2455-2143, Pages 29-42 \\ Published Online May 2021 in IJEAST (http://www.ijeast.com)}

The cultivated area $\left(540 \mathrm{~m}^{2}\right)$ is divided in 13 parts to grow different vegetables with an area of $41.54 \mathrm{~m}^{2}$ for each species. Table 3 shows the calculations of the expected yield per year and results show that 1.7 tons per year could be produced from this area.

Table 3 Summary of the yield per year

\begin{tabular}{|c|ccc|}
\hline Vegetables & $\begin{array}{c}\text { Yield } \\
(\mathbf{q} / \mathbf{H a})\end{array}$ & $\begin{array}{c}\text { Area } \\
\text { cultivated } \\
\left(\mathbf{m}^{\mathbf{2}}\right)\end{array}$ & $\begin{array}{c}\mathbf{q} \text { per } \\
\mathbf{4 1 . 5 4} \\
\mathbf{~ m}^{\mathbf{2}}\end{array}$ \\
\hline Carrots & 400 & 41.54 & 1.7 \\
\hline Beans & 40 & 41.54 & 0.2 \\
\hline Fennel & 400 & 41.54 & 1.7 \\
\hline Tomato & 800 & 41.54 & 3.3 \\
\hline Broccoli & 200 & 41.54 & 0.8 \\
\hline Lettuce & 300 & 41.54 & 1.2 \\
\hline Potatoes & 250 & 41.54 & 1 \\
\hline Cucumber & 250 & 41.54 & 1 \\
\hline Onion & 300 & 41.54 & 1.2 \\
\hline Spinach & 200 & 41.54 & 0.8 \\
\hline Pumpkin & 500 & 41.54 & 2.1 \\
\hline Parsley & 300 & 41.54 & 1.2 \\
\hline Chamomile & 165 & 41.54 & 0.69 \\
\hline
\end{tabular}

\section{Source: Authors}

\section{Irrigation system}

The irrigation system used would drip irrigation linked with sensors for the humidity of the soil. A higher control of water waste is possible with this technological system:

- By raising shrubberies, it can take advantage of water drainage to irrigate plants;

- Part of water used for irrigation comes from rain collected in an underground water-tank with $5,000 \mathrm{~L}$ capacity (SIR5075 model, from ROTOTEC ${ }^{\circledR}$ ). The choice of this capacity derives from the annual amount of rain and the estimated water needs for the garden that is $6.5 \mathrm{~m}^{3}$ for $540 \mathrm{~m}^{2}$.

\section{Composting}

The area will be provided with compost bins, with a comprehensive capacity of 3000 Litres. The structure will be handmade using pallets, while initial bacteria and microorganisms will be inoculated to make the composting process faster. An opening at the bottom of the bin will be necessary to harvest the mature compost, produced after 9-12 months, to fertilize the fields. The compost bin will be filled up with vegetable waste from the synergic garden, aquaponic and the kitchen. To cover the initial nutrient needs of plants, high quality compost from local farmers is used.

\section{BUSINESS MODEL}

One of the project's goals is to be socially, environmentally and economically sustainable. Through the business model, it is possible to set the structure of the project when in operation and to calculate the costs and revenues. The project is summarized in a lean canvas as shown in Table 4.

\subsection{Products and services provided}

Our project operates on a multifunctional basis that provides the community with different services. Those services could be summarized as follows:

a. Organic Food Sales. The farm sells organic food at the same time in the premises, at Lanuvio's market and through a "mobile market" on bicycles.

b. Rental of farming facilities. The locals can rent part of the farm's facilities annually where they can plant and harvest their own produce. While doing so, they are also revealed to farming techniques.

c. Events and socializing area. Through the recreational and social events area, the locals can interact with each other and with the tourists.

d. Workshops - the workshop room is where different classes and seminars are given to raise awareness about organic food planting, innovative farming techniques and permaculture, yet the kitchen gives lessons in basics of cooking.

e. Yoga Classes. Weekly courses hosted in our facilities, thanks to a specialized teacher, opened to anyone, subject to the purchase of a ticket.

\subsection{Targeted Customers}

Our farm targets a wide spectrum of users who interact together and exchange ideas. Different groups could be identified as: 


\section{International Journal of Engineering Applied Sciences and Technology, 2021 \\ Vol. 6, Issue 1, ISSN No. 2455-2143, Pages 29-42 \\ Published Online May 2021 in IJEAST (http://www.ijeast.com)}

Table 4 Lean canvas model of the project

\section{Lean Canvas Model}

\section{PROBLEM}

1. Basic need of fresh healthy products

2. space and technology for small innovative production

3. Lack of popularity

\section{EXISTING} AKTERNATIVES

At a local level:

1. Cooperatives selling and transforming products

2. Didactic farms 3. Socials

\section{SOLUTION}

1. Product Selling

2. Rent of farming facilities

3. Events

4. Workshops and

kitchen lessons

5. Advertisement on the app

\section{KEY METRICS}

The focus is on:

- Events: at least 2

- Rent facilities: 16

columns and 18 trays

\section{COST STRUCTURE}

Establishment costs for technologies Labor - voluntaries (0€)
UNIQUE VALUE PROPOSITION innovative way to produce or to approach environmental sustainability, thanks to:

-Vanguard techniques -Sustainable environment

\section{HIGH-LEVEL CONCEPT}

\section{UNFAIR ADVANTAGE}

site of Lanuvio: naturalistic values to promote, closeness to villa Sforza

CHANNELS

- Agricultural workers associations

- Social media and events

\section{CUSTOMER} SEGMENTS

1. Consumers of local markets, typically families, elders

2. Local farmers, the younger ones from 35 to 50 years old

3. Young families with children

4. Groups: students from 6 to 13 years old with teachers 5. Other social sustainable producers

\section{REVENUE STREAMS}

1. Weekly sales, based on seasons

2. Rent

3. Tickets

4. Fee on sales

\section{Source: Authors}

a. Local Community: This is anyone who is living in Lanuvio and is looking out for consuming organic food or to learn about agriculture technologies to apply them in their backyard farms.

b. Tourists: as the area is naturally full of historic sites, many tourists are visiting it.

c. Volunteers: The farm welcomes all volunteers that could love new innovative experiences of work, whether they are from the direct community or international volunteers.

d. School Students: Since the farm spreads awareness and learning, students are especially targeted through periodic workshops and events, in which local schools may be directly involved.

\subsection{Organisational Structure}

The structure that best suits the mission of our project is the so called "social cooperative", which, from the regional law, "is the one that promotes, supports and sustains human development and social integration with particular regarding of disadvantaged people", in particular the one related to the agricultural field (type B). As allowed by the law, our team will be made of volunteers (up to a maximum of half of the entire team) and specialized workers to handle the maintenance of the plantations.

\subsection{Fundings}

Starting from the Region, already from last year some announcements were published offering subsidies for "social cooperative of type B" as we are, with the aim of "sustaining the social and working integration of disadvantaged people. A fund comes from the MISE (Ministry of Economic Development) that offers specific public funding's in favour of the birth of small cooperatives, with an allocated amount of 223 million $€$, which provide a feasible way to subscribe to the initial investment required. The Italian government also offers both non-repayable subsidies and easy credit terms loans for the initial investment. The law provides up to a maximum of $40 \%$ of the expenses for "market analysis, land, buildings, machineries and any other goods required for the production" as listed in details in Table 4 - Appendix A.

\subsection{Cost Analysis}

This analysis has to follow the natural path of the project itself. Initially, a critical investment would be required to cover the renovation of the buildings, the technologies, and so on, as shown in Table 5 (Appendix A). An initial investment of $380,000 €$ is expected, of which some expenses 


\section{International Journal of Engineering Applied Sciences and Technology, 2021 \\ Vol. 6, Issue 1, ISSN No. 2455-2143, Pages 29-42 \\ Published Online May 2021 in IJEAST (http://www.ijeast.com)}

would be covered by the previously explained funding's, and leave for an actually required initial investment of $250,000 €$ (refer to the operating margin below). Of course, every operating year, some expenses will be required for the maintenance and the activities pursued within the farm, as shown in Table 6 (Appendix A), for which we expect about $28,000 €$ of costs per year.

\subsection{Revenue Stream Analysis}

The biggest percentage of revenue is provided by the kitchen classes (74\%) followed by the rent of the hydroponic columns (19\%). The amount considered is the value of the yearly production from all the columns that can be guaranteed to those renting them. Details of this calculation are shown in Table 7 (Appendix A). For yoga classes, the revenue is fixed as $15 \%$ on the hypothetical fee requested by the teacher to its clients. An average yoga course could cost $€ 60 /$ month for 2 lessons per week, considering 20 clients per lesson. For details, refer to Table 8 (Appendix A). Moreover, tickets vary for the type of lessons proposed in the kitchen, as shown in Table 9 (Appendix A). All the different sources of revenue are shown in Table 5.

Table 5 Sources of revenue with percentage

\begin{tabular}{|c|c|c|}
\hline Item & $\begin{array}{r}\text { Yearly } \\
\text { Revenues in } \\
\text { Euro }\end{array}$ & $\begin{array}{l}\% \text { of Total } \\
\text { Revenues }\end{array}$ \\
\hline $\begin{array}{l}\text { Rent of the } \\
\text { hydroponic } \\
\text { columns }\end{array}$ & $19,588 €$ & $19,4 \%$ \\
\hline $\begin{array}{c}\text { Sales of products } \\
\text { from } \\
\text { permaculture }\end{array}$ & $2,269 €$ & $2,2 \%$ \\
\hline Yoga classes & $2,160 €$ & $2,1 \%$ \\
\hline Kitchen classes & $74,850 €$ & $74,1 \%$ \\
\hline Sales of fishes & $2,100 €$ & $2,1 \%$ \\
\hline Total & $100,967 €$ & $100,0 \%$ \\
\hline
\end{tabular}

\subsection{Operation Margin and ROI}

The initial investment, funding's, operating costs and revenues, were summarized previously to calculate the operating margin and return on investments (ROI). The data produced refers to a fully operating year. A positive operating margin of about $€ 73,000$ is expected, that is particularly favorable. In addition, the ROI is also in an optimum position (19\%), due to the funding's that allow us to reduce the "weight" of the initial investments. Table 6 summarizes the calculation of the operating margin and ROI. Noteworthy is that even with the first years being less benefiting, the investments are paid off after a maximum of five years.

Table 6 Operating Margin and ROI calculations

\begin{tabular}{|cr|}
\hline Feasibility calculation & \\
\hline Initial investment - total & $383,766 €$ \\
\hline Granted initial funds & $137,051 €$ \\
Costs uncovered by funds & $246,714 €$ \\
\hline Required initial investment & $250,000 €$ \\
(approximation) & \\
Operation & $100,967 €$ \\
\hline Operating revenues (per year) & $27,954 €$ \\
Operating costs (per year) & $73,013 €$ \\
Operating margin (per year) \\
\hline ROI calculation \\
Investment costs (funds included) \\
Profit of the year \\
ROI \\
\hline
\end{tabular}

\section{RESULTS AND DiSCUSSION}

The results are analyzed by stating the features and the technologies implemented in the project and its impact on the economic, social and environmental sustainability. Table 7 shows a summary for all the interventions done in the project to analyze how sustainable the project is through extracting some percentages regarding the three pillars of sustainability. Also, the final results 3D visualizations are shown in Figure 14 to 19 . Figure 14 illustrates the whole site being developed as a bird's eye view. Figure 15 shows the view from the main entrance. In Figure 16, the integration of greens in the project is shown where the main elevation includes green walls. Moreover, Figure 17 shows the kitchen where people can learn cooking. Figure 18 presents the main section through the main building integrating different technologies in the indoors as the one space luminous, the aquaponic and the rain water harvesting systems. Figure 19 shows the main elevation of the main building where different technologies are found as the information technology system, the green walls and the solar panels for saving energy. 


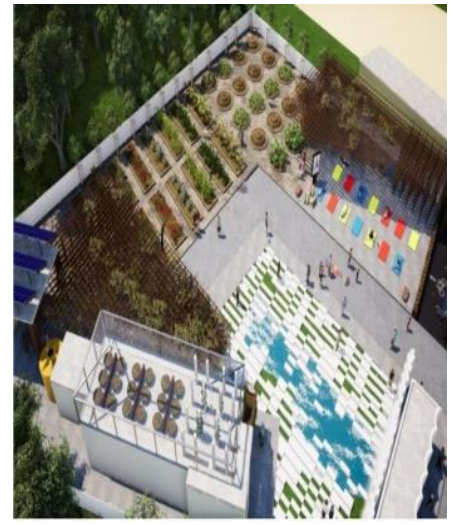

Fig. 14 Developed site after incorporating all urban farming technologies

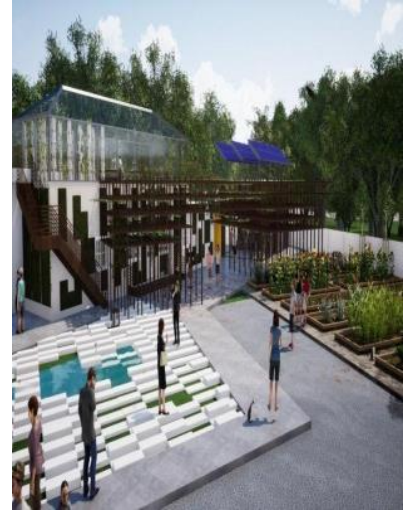

Fig. 15 Site entrance with various features

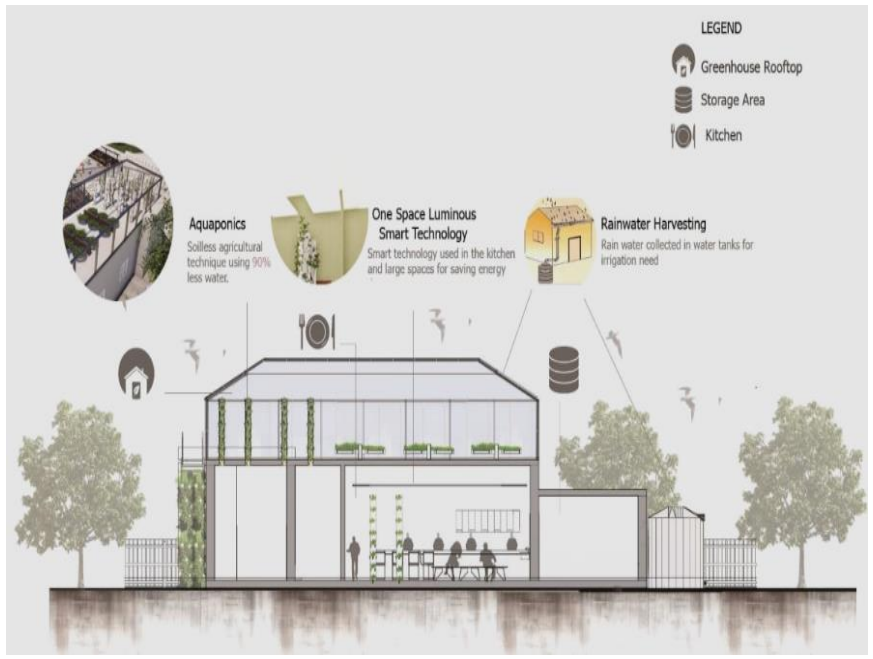

Fig. 18 Section through the main building Image credit: Authors

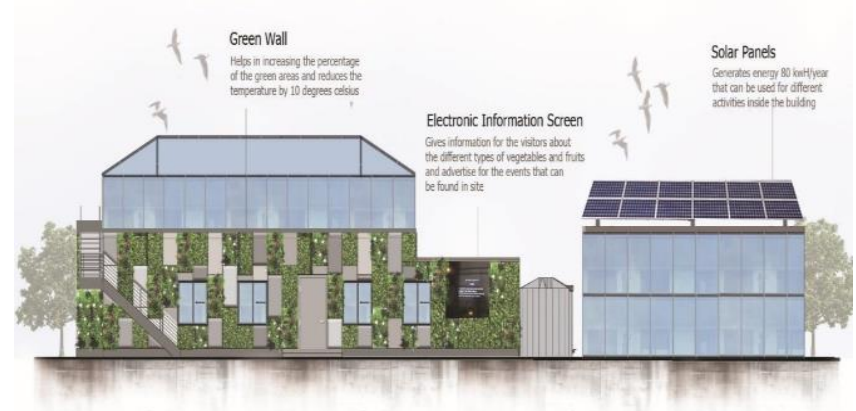

Fig. 19 The main elevation of the green walls, information boards and solar panels

Image credit: Authors

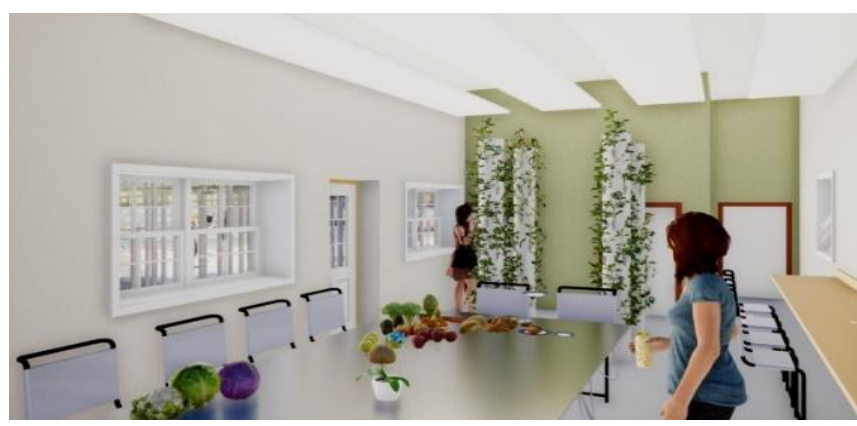

Fig. 17 Interior of the kitchen in the building Image credit: Authors, 2020 


\section{International Journal of Engineering Applied Sciences and Technology, 2021 \\ Vol. 6, Issue 1, ISSN No. 2455-2143, Pages 29-42 \\ Published Online May 2021 in IJEAST (http://www.ijeast.com)}

Table 7 Sustainable development pillars assessment of the project

\begin{tabular}{|c|c|c|c|c|}
\hline No. & Mission & $\begin{array}{l}\text { Economic } \\
\text { Sustainability }\end{array}$ & $\begin{array}{l}\text { Social } \\
\text { Sustainability }\end{array}$ & $\begin{array}{l}\text { Environmental } \\
\text { Sustainability }\end{array}$ \\
\hline 1 & $\begin{array}{l}\text { Presence of various functions indoors and } \\
\text { outdoors }\end{array}$ & $\checkmark$ & $\checkmark$ & NA \\
\hline 2 & keeping the old building structure & $\checkmark$ & NA & $\checkmark$ \\
\hline 3 & Host music festivals & $\checkmark$ & $\checkmark$ & NA \\
\hline 4 & Blend Music and Agriculture in one space & NA & $\checkmark$ & NA \\
\hline 5 & Create workshop for raising awareness & $\checkmark$ & $\checkmark$ & NA \\
\hline 6 & $\begin{array}{l}\text { Create a space for restaurant \& organic food } \\
\text { market }\end{array}$ & $\checkmark$ & NA & NA \\
\hline 7 & $\begin{array}{l}\text { Integrate the production area with the selling, } \\
\text { tasting and crafts area }\end{array}$ & $\checkmark$ & NA & NA \\
\hline 8 & $\begin{array}{l}\text { Create one universal space shared by all types of } \\
\text { users }\end{array}$ & NA & $\checkmark$ & NA \\
\hline 9 & Rental of farming facilities & $\checkmark$ & $\checkmark$ & $\checkmark$ \\
\hline 10 & Architectural sustainable technologies & $\checkmark$ & NA & $\checkmark$ \\
\hline 11 & Synergic garden (with permaculture technique) & $\checkmark$ & $\checkmark$ & $\checkmark$ \\
\hline 12 & Green Walls & NA & NA & ' \\
\hline 13 & Aquaponic system & $\checkmark$ & NA & $\checkmark$ \\
\hline 14 & Greenhouse with hydroponic columns & $\checkmark$ & NA & $\checkmark$ \\
\hline 15 & Redevelopment of the building & $\checkmark$ & $\checkmark$ & $\checkmark$ \\
\hline 16 & $\begin{array}{l}\text { Providing education for plant production, cooking } \\
\& \text { managerial skills }\end{array}$ & $\checkmark$ & $\checkmark$ & $\checkmark$ \\
\hline & Total achieved & $13 / 16$ & $9 / 16$ & $9 / 16$ \\
\hline & & $81 \%$ & $56 \%$ & $56 \%$ \\
\hline
\end{tabular}

\section{Conclusions}

Green Symphony project achieved its set of objectives by integrating the urban farm with its surrounding urban context. Also, this project covers all three pillars of sustainability; environmental, social and economic aspects to achieve a selfsustained site creating new jobs. In addition, it provides clean and safe vegetables and a productive hub for the city. Blending music, architecture and agriculture creates connectivity and social innovation through the variety of social spaces. Moreover, the project helps in creating livable, healthy and sustainable urban environments in the commune of Lanuvio, in the metropolitan city of Rome, Italy.

The project re-development contributes to attaining SDGs, particularly SDG 3, 7, 9, 11, 12, 13, and 15 .

\section{REFERENCES}

1 McKinsey Global Institute (2011). Urban world: Mapping the economic power of cities. [Online], available at: https://www.mckinsey.com/ /media/McKinsey/Feature d\%20Insights/Urbanization/Urban\%20world/MGI_urb an_world_mapping_economic_power_of_cities_full_re port.pdf.

2 Avtar, R.; Tripathi, S.; Aggarwal, A.K.; Kumar, P. (2019) Population-Urbanization-Energy Nexus: A Review. Resources, (pp. 8-136).

3 Sims, R., Schaeffer, F. et al, (2014). Transport. In: Climate Change 2014: Mitigation of Climate Change. Contribution of Working Group III to the Fifth Assessment Report of the Intergovernmental Panel on Climate Change. Cambridge University Press, 


\section{International Journal of Engineering Applied Sciences and Technology, 2021 \\ Vol. 6, Issue 1, ISSN No. 2455-2143, Pages 29-42 \\ Published Online May 2021 in IJEAST (http://www.ijeast.com)}

Cambridge, United Kingdom and New York, NY, USA. Retrieved from: https://www.sciencedirect.com/science/article/pii/S235 2146517308098./

4 Elasha, B. (2010). Mapping of Climate Change Threats and Human Development Impacts in the Arab Region (Rep.). UNDP. Retrieved from: http://www.arabclimateinitiative.org/knowledge/backgr ound/Balgis_mapping\%20CC\%20threats\%20and\%20h uman\%20dev\%20impacts\%20in\%20Arab\%20region.p $\underline{\mathrm{df}}$

5 Seneviratne, S.; Nicholls, N.; Easterling, D.; Goodness, C.M. (2012). Changes in climate extremes and their impacts on the natural physical environment: An overview of the IPCC SREX report,(Pg. 3)

6 United Nations, (2018). Global Status Report 2018. Retrieved from: https://www.unenvironment.org/resources/report/global -status-report-2018

7 Sivaramanan, Sivakumaran. (2015). Global Warming and Climate change, causes, impacts and mitigation. 10.13140/RG.2.1.4889.7128 [MA1].

8 World Health Organization, (2018). Climate change and health country profile: Italy. Retrieved from: https://apps.who.int/iris/handle/10665/260380.

9 Hallett, Steve \& Hoagland, Lori \& Toner, Emily. (2016). Urban Agriculture: Environmental, Economic, and Social Perspectives. 10.1002/9781119281269.ch2.

10 Binns, T., \& Amp; Nel, E. (2012). The significance of urban agriculture in food security and sustainable livelihoods in response to economic restructuring in Zambia's copper belt province (Rep.). Global education programme international development research fund.

11 Kennard, Nicole \& Bamford, Robert. (2020). Urban Agriculture: Opportunities and Challenges for Sustainable Development. 10.1007/978-3-319-696263_102-1.

12 Olivier, D. (2015). The physical and social benefits of urban agriculture projects run by non-governmental organisations in Cape Town (Unpublished master's thesis). Stellenbosch University. Retrieved from: https://core.ac.uk/download/pdf/37438493.pdf.

13 Orsini, Francesco; Kahane, Remi.; Nono Womdim.; Gianquinto, Giorgio. (2013). urban agriculture in the developing world: A review. Agronomy for Sustainable Development.(pp 33. 695-720). 10.1007/s13593-0130143-z.

14 Potutan GE,; Schnitzler WH,; Arnado JM,; Janubas LG, Holmer RJ (2000) Urban agriculture in Cagayan de Oro: a favourable response of city government and NGOs. In: Bakker N,; Dubbeling M,; Guendel S,;
Sabel Koschella U,; de Zeeuw H (eds) Growing cities, growing food, urban agriculture on the policy Agenda. DSE, Feldafing, (pp. 413-428).

15 Cruz MC and Medina RS (2003) Agriculture in the city: a key to sustainability in Havana, Cuba. Ian Randle, Kingston. http://www.idrc.ca/openebooks/104-3/.

16 Purnomohadi, N., (2000) Jakarta: Urban agriculture as an alternative strategy to face the economic crisis. In: Bakker N, Dubbeling M., Guendel S., Sabel Koschella U., de Zeeuw H., (eds) Growing cities, growing food, urban agriculture on the policy Agenda. DSE, Feldafing, (pp 453-466).

17 Farming in urban areas can boost food security, (2005) Retrieved

from https://www.fao.org/newsroom/en/news/2005/102877/i ndex.html.

18 Smit, J.; Nasr, J.; Ratta, A. (2001). Producing Food and Fuel in Urban Areas. In Urban agriculture: Food, jobs, and sustainable cities. Published with permission from the United Nations Development Programme. (Chapter $5)$.

19 Jena, Alok Kumar.; Biswas, Pradyut.; Saha, Himadri. (2017). ADVANCED FARMING SYSTEMS IN AQUACULTURE: STRATEGIES TO ENHANCE THE PRODUCTION. Innovative Farming, (pp 24556521, 2. 84-89).

20 Employing aeroponics as growing method. (n.d.). Retrieved

from:

https://seattleurbanfoodsource.weebly.com/growthresearch.html.

21 Green Wall. (n.d.). Retrieved from: https://verdeprofilo.com/en/vertical-gardening/greenwall.

22 Beacham, Andrew. Vickers, Laura. Monaghan, Jim (2019). Vertical farming: a summary of approaches to growing skywards. The Journal of Horticultural Science and Biotechnology. (pp. $94 . \quad 1-7$ ). 10.1080/14620316.2019.1574214.

23 Lanuvio. (n.d.). Retrieved from: https://www.summerinitaly.com/guide/lanuvio.

24 Deutsche Welle (DW). (2019). [Image]. Retrieved from https://www.dw.com/en/promoting-urban-farming-inugandas-schools/av-48108246.

25 WOHA Architects. Raising the roof: Cultivating Singapore's urban farming scene [Image]. Retrieved from

https://cnaluxury.channelnewsasia.com/experiences/urb an-farming-singapore-11925958

26 Kadapa-Bose, S. (2019). Soil-less \& Vertical, This Style of Farming Will Reduce Water Usage By 95\%! [Image]. Retrieved

from 


\section{International Journal of Engineering Applied Sciences and Technology, 2021 \\ Vol. 6, Issue 1, ISSN No. 2455-2143, Pages 29-42 \\ Published Online May 2021 in IJEAST (http://www.ijeast.com)}

https://www.thebetterindia.com/199411/how-tovertical-farming-hydroponics-fresh-produce-organicindia/.

27 Barnett, S. (2013). Urban agriculture in South Africa [Image]. Retrieved from https://ozcf.co.za/2013/02/07/urban-agriculture-insouth-africa-food-in-the-city/on-the-roof-768x1024/. Accessed: August 17, 2020.

28 You Matter. (2020). What is the Aquaponics System? Definition, Benefits, Weaknesses [Image]. Retrieved from https://youmatter.world/en/definition/aquaponicssustainable-benefits-system/.

29 Huifa. PVC Pipe Flat Hydroponic Growing System [Image]. Retrieved from https://www.hfgreenhouse.com/products/hydroponicsystem/.

30 Outdoor Design Source (ODS). (2016). VICINITY GREENWALL SYSTEMS 14 Jun 2016, 3991 views [Image]. Retrieved from https://www.outdoordesign.com.au/news-info/vicinitygreenwall-systems/4492.htm.

31 Markillie, P. Vertical farms on the rise [Image]. Retrieved from

https://worldin.economist.com/article/17522/edition202 0vertical-farmsrise.

32 UrbanFarm 2020 International Challenge [Online], available at: https://site.unibo.it/urbanfarm/en/thechallenge/urbanfarm-2020.

Phoenix mythological bird. Retrieved from: https://www.britannica.com/topic/phoenixmythological-bir.
PVWatts
Calculator.
Retrieved
from: https://pvwatts.nrel.gov/.

ARPA. Radar meteo: stima della pioggia | Servizio IdroMeteo-Clima | ArpaER retrieved from: https://www.arpae.it/sim/?osservazioni_e dati/radar.

Ayaz, Muhammad.; Uddin, Ammad.; Sharif, Zubair.; Mansour, Ali.; Aggoune, el-Hadi. (2019). Internet-ofThings (IoT)-Based Smart Agriculture: Toward Making the Fields Talk. IEEE ( PP. 1-1. 10.1109)

37 Orti, G.; Associazione, A.; Manifesto, C. (2014). Civiltà Contadina Associazione per la salvaguardia della biodiversità. Retrieved from: https://www.civiltacontadina.it/.

38 ADEME. (2015). ADEME - Bilans GES Site retrieved from:

https://www.bilansges.ademe.fr/en/basecarbone/donnee s-consulter/choix-categorie.
39 Impatto Zero srl, Acquaponica, la redditività che non avete mai visto, Agricoltura 2.0, 2018 retrieved from: https://agricoltura2punto0.it/IT/ct/Mg/Azienda..

40 Hunter, C. (2020). Cinnamon Herbal Properties: Traditional Herbal Medicinal Use [Image]. Retrieved from: https://www.thepracticalherbalist.com/advancedherbalism/cinnamon-herbal-properties-traditionalherbal-medicinal-use.

41 Burpee. (2020). Tomato, Sun Gold Hybrid [Image]. Retrieved from: https://www.burpee.com/vegetables/tomatoes/tomatosun-gold--hybrid-prod001012.html.

42 Zaden, E. (2020). [Image]. Retrieved from: https://www.enzazaden.com/uk/products-andservices/our-products/Herbs/Staro.

43 Almost Eden. (2020). Calypso Oleander [Image] Retrieved from https://www.almostedenplants.com/shopping/products/ 348-calypso-oleander/.

Plants with a purpose. (2019). Dill, Bouquet Dill [Image]. Retrieved from: https://plantswithapurpose.net/product/dill-bouquetdill/.

45 High Country Gardens. Standing Ovation Little Bluestem Grass [Image]. Retrieved from: https://www.highcountrygardens.com/perennialplants/ornamental-grass/schizachyrium-standingovation-little-bluestem.

MaskaRad. (2018). Radish Planting Tips: How To Plant Radishes In The Garden [Image]. Retrieved from: https://www.gardeningknowhow.com/edible/vegetables /radish/tips-how-plant-radish.htm. August 17, 2020.

47 Seedway. Crunchy Royale (Treated Seed) [Image]. Retrieved from: https://www.seedway.com/product/9457-crunchyroyale-treated-seed/.

48 Caribbeangardenseed. Ethiopian Kale Seeds, Ethiopian Mustard, Abyssinian Mustard, African Kale, Highland Kale [Image]. Retrieved from https://www.caribbeangardenseed.com/products/organi c-lacinato-kale-seeds-also-know-as-dinosaur-kaletuscan-kale-and-even-flat-black-cabbage-heirloomcold-hardy-vegetable

49 Mizuna Gardens. [Image]. Retrieved from http://reneeoberdorf-34hn.squarespace.com/other-greens/. 